\title{
EFEKTIVITAS PELATIHAN PENGENDALIAN DIRI UNTUK MENGATASI PERILAKU BULLYING SISWA DI SMP NEGERI 19 AMBON
}

\author{
Jeanete Ophilia Papilaya, M.Psi ${ }^{1}$ Nessy Pattimukay, M.Pd ${ }^{2}$ \\ ${ }^{1}$ Dosen pada Program Studi Bimbingan Konseling FKIP Universitas Pattimura-Ambon \\ ${ }^{2}$ Dosen pada Program Studi Pendidikan Guru Sekolah Dasar FKIP Universitas Pattimura-Ambon
}

\section{ARTICLE INFO}

Article History:

Accepted 11 Septermber 2017

Available online 18 Oktober 2017

Keywords:

Self-Control Training, Bullying Behavior.

\begin{abstract}
This study purpose to a) assess the effectiveness of self-control training to address bullying behavior of students, b) Conduct training self-control to overcome the bullying behavior of students. To achieve that goal then used experimental research design with the onegroup pretest-posttest design. hypotheses used are effective self-control training to resolve bullying behavior of students. Data obtained from 24 students who demonstrate bullying behavior. Analysis using $t$ test with SPSS version 16.0 of the calculation of the results found $t>t$ table (7232>1714). From the results of t-test analysis found that effective self-control training to address bullying behavior of students.
\end{abstract}

\section{PENDAHULUAN}

Tujuan pendidikan nasional sesuai dengan UU SISDIKNAS No. 20 Tahun 2003 Bab II Pasal 3 yaitu Pendidikan nasional bertujuan untuk berkembangnya potensi peserta didik agar menjadi manusia yang beriman dan bertaqwa kepada Tuhan Yang Maha Esa, berakhlak mulia, sehat, berilmu, cakap, kreatif, mandiri, dan menjadi warga Negara yang demokratis serta bertanggung jawab. Bertolak dari tujuan pendidikan nasional tersebut maka diharapkan sekolah sebagai lembaga pendidikan dapat mewujudkan suasana pembelajaran dan proses pembelajaran agara siswa secara aktif mengembangkan potensi dirinya untuk memiliki kekuatan spiritual keagamaan, 
pengendalian diri, kepribadian, kecerdasan, penanaman nilai-nilai sikap dan perilaku dalam rangka mencerdaskan kehidupan bangsa.

Proses pembelajaran di sekolah, diharapkan guru bukan hanya mengajar tetapi juga bisa menanamkan nilai-nilai sikap dan perilaku yang positif kepada siswa. Pada kenyataannya, guru di sekolah hanya melakukan tugasnya untuk mengajar, guru kurang peka terhadap perilaku siswa. Perilaku siswa di sekolah banyak dipengaruhi oleh lingkungan pergaulan teman sebaya. Hal ini menyebabkan tidak sedikit siswa mengembangkan perilaku negative ketika di sekolah. Siswa menunjukkan perilaku yang melanggar norma. Oleh karena itu, banyak siswa yang terlibat dalam perkelahian atau tawuran, bolos sekolah, pembangkang, agresif secara fisik dan verbal, dan bullying.

Hasil konsultasi Komisi Nasional Perlindungan Anak dengan anak-anak di 18 Provinsi Indonesia memperlihatkan bahwa sekolah juga bisa menjadi tempat yang cukup berbahaya bagi siswa (Sumiarni, 2009). Bullying dapat mengubah kegiatan di sekolah yang awalnya menyenangkan, belajar sambil berteman menjadi menakutkan. Hal ini diperkuat dengan survey anti bullying yang dilakukan oleh Yayasan Sejiwa (2007) yang menghasilkan bahwa 94,9\% bullying terjadi di sekolah-sekolah di Indonesia.

Fenomena bullying juga terjadi di pada siswa SMP Negeri 19 Ambon. Hasil observasi awal menunjukkan bahwa banyak siswa yang melakukan bullying terhadap siswa yang lain. Perilaku bullying yang dilakukan oleh siswa berupa memberikan julukan nama yang membuat siswa lain menjadi tidak nyaman dengan julukan tersebut, celaan, penghinaan, intimidasi, pemalakan, mengejek, mengancam, dan mengucilkan.

Bullying bukanlah merupakan suatu tindakan yang kebetulan terjadi, melainkan dipengaruhi oleh beberap faktor, seperti faktor sosial, budaya, dan ekonomi. Biasanya dilakukan oleh pihak-pihak yang berasa lebih kuat, lebih berkuasa, atau bahkan merasa lebih terhormat untuk menindas pihak lain untuk memperoleh keuntungan tertentu. Hal ini sejalan dengan pendapat Soendjojo (2009) yang mengatakan bahwa siswa yang melakukan bullying adalah siswa yang superior, merasa diri lebih dari orang lain, dan kurang adanya pengendalian diri. Siswa yang melakukan bullying cenderung tidak dapat mengendalikan dirinya untuk mengintimidasi orang lain.

Pengendalian diri merupakan salah satu aspek yang penting yang seharusnya dimiliki oleh siswa dalam proses pendidikan karena sejalan dengan tujuan pendidikan nasional. Siswa seharusnya dapat membedakan perilaku yang dapat diterima dan yang tidak dapat diterima, namun siswa yang melakukan bullying tidak mengenali hal ini. Hal ini juga bisa dikarenakan mungkin mereka sebenarnya telah mengetahui 
perbedaan keduanya namun gagal mengembangkan kontrol yang memadai dalam menggunakan perbedaan itu dalam perilaku (Santrock, 2002).

Senada dengan pendapat Santrock, Averil (Ghufron dan Risnawita, 2010) juga mengemukakan aspek pengendalian diri adalah pengendalian perilaku, pengendalian kognisi, dan pengendalian keputusan. Aspek pengendalian diri yang dilatih akan bergerak dari ranah kognisi, lalu keputusan, kemudian perilaku individu, sehingga ketiga aspek tersebut akan dapat mengatasi perilaku bullying yang dimiliki oleh siswa. Siswa yang diberikan pelatihan pengendalian diri diharapkan dapat menghilangkan kecenderungan perilaku bullying di sekolah.

Berdasarkan latar belakang diatas, maka peneliti ingin meneliti tentang efektivitas pelatihan pengendalian diri untuk mengatasi perilaku bullying siswa di SMP Negeri 19 Ambon.

\section{KAJIAN PUSTAKA}

Bullying adalah perilaku agresif yang dilakukan secara sengaja terjadi berulangulang untuk menyerang seorang target atau korban yang lemah, mudah dihina dan tidak bisa membela diri sendiri (Sejiwa, 2007). Bullying juga didefinisikan sebagai kekerasan fisik dan psikologis jangka panjang yang dilakukan seseorang atau kelompok, terhadap seseorang yang tidak mampu mempertahankan dirinya dalam situasi di mana ada hasrat untuk melukai atau menakuti orang itu atau membuat dia tertekan (Wicaksono, 2008).

Menurut Mudjijanti (2011), penyebab terjadinya bullying antara lain : (a) keluarga, Pelaku bullying seringkali berasal dari keluarga yang bermasalah : orang tua yang sering menghukum anaknya secara berlebihan, atau situasi rumah yang penuh stress, agresi, dan permusuhan. Anak akan mempelajari perilaku bullying ketika mengamati konflik-konflik yang terjadi pada orang tua mereka, dan kemudian menirunya terhadap teman-temannya. (b) Sekolah, pihak sekolah sering mengabaikan keberadaan bullying ini, anak-anak sebagai pelaku bullying akan mendapatkan penguatan terhadap perilaku mereka untuk melakukan intimidasi terhadap anak lain. Bullying berkembang dengan pesat dalam lingkungan sekolah sering memberikan masukan negatif pada siswanya. (c) Teman Sebaya, Anak-anak ketika berinteraksi dalam sekolah dan dengan teman di sekitar rumah, kadang kala terdorong untuk melakukan bullying. Beberapa anak melakukan bullying dalam usaha untuk membuktikan bahwa mereka bisa masuk dalam kelompok tertentu, meskipun mereka sendiri merasa tidak nyaman dengan perilaku tersebut.

Menurut Ribgy (Astuti, 2008) tindakan bullying mempunyai tiga karakteristik terintegrasi, yaitu: (a). Adanya perilaku agresi yang menyenangkan pelaku untuk menyakiti korban. (b) tindakan dilakukan secara tidak seimbang sehingga korban 
merasa tertekan. (c) perilaku ini dilakukan secara terus menerus dan juga berulangulang.

Ada beberapa jenis bullying menurut SEJIWA (2007), yaitu (1) Bullying fisik, Jenis bullying yang terlihat oleh mata, siapapun dapat melihatnya karena terjadi sentuhan fisik antara pelaku bullying dan korbannya. Contoh - contoh bullying fisik antara lain : memukul, menarik baju, menjewer, menjambak, menendang, menyenggol dengan bahu, menghukum dengan membersihkan WC, menampar, menimpuk, menginjak kaki, menjegal, meludahi, memalak, melempar dengan barang, menghukum dengan berlari lapangan, menghukum dengan cara push up. (2) Bullying verbal, Jenis bullying yang juga bisa terdeteksi karena bisa terungkap indra pendengaran kita. Contoh - contoh bullying verbal antara lain : membentak, meledek, mencela, memaki - maki, menghina, menjuluki, meneriaki, mempermalukan didepan umum, menyoraki, menebar gosip, memfitnah. (3) Bullying mental atau psikologis, Jenis bullying yang paling berbahaya karena tidak tertangkap oleh mata atau telinga kita apabila tidak cukup awas mendeteksinya. Praktik bullying ini terjadi diam - diam dan diluar jangkauan pemantauan individu. Contoh - contohnya: mencibir, mengucilkan, memandang sinis, memelototi, memandang penuh ancaman, mempermalukan di depan umum, mendiamkan, meneror lewat pesan pendek, telepon genggam atau email, memandang yang merendahkan.

Pengendalian diri merupakan kenderungan individu untuk mempertimbangkan berbagai konsekuensi untuk perilaku tertentu (Tangney, Baumiester, \& Boone, 2004). Selain itu, pengendalian diri adalah kemampuan individu untuk menahan diri atau mengarahkan diri ke arah yang lebih baik ketika dihadapkan dengan godaan-godaan (Tangney, Baumiester, \& Boone, 2004). Pengendalian diri dikatakan sebagai kemampuan manusia untuk menahan dan mengendalikan perilaku sosial yang tidak pantas (Tangney, Baumiester, \& Boone, 2004). Hal ini diperkuat oleh hasil penelitian Denson, DeWall,dan Finkel (2012) yang menyatakan bahwa kegagalan self-control dapat memberikan kontribusi untuk tindakan yang paling agresif yang menyertakan kekerasan.

Dari hasil penelitiannya, Chapple (2005) menyimpulkan bahwa pengendalian diri yang rendah menyebabkan penolakan dari rekan sesama (peer rejection), hubungan dengan rekan atau kelompok yang menyimpang (deviant peer) dan kenakalan (delinquency).

Averil (Ghufron dan Risnawita, 2010) mengemukakan aspek pengendalian diri adalah (1) Pengendalian perilaku, yang meliputi mampu mengendalikan keinginan di dalam dirinya, mampu mengendalikan situasi di luar dirinya, dan mampu merubah stimulus yang tidak menyenangkan menjadi menyenangkan. (2) Pengendalian kognisi, yang meliputi mampu memahami dan mengenali berbagai stimulus, mampu 
menilai suatu keadaaan lingkungannya dengan baik, mampu melakukan antisipasi terhadap stimulus yang tidak diharapkan. (3) Pengendalian keputusan, yang meliputi mampu mengambil tindakan atas permasalahan yang dihadapi, mengambil tindakan tanpa melibatkan kebutuhan pribadi, dan mempertimbangkan dari berbagai sisi sebelum mengambil suatu tindakan.

\section{HIPOTESIS PENELITIAN}

Adapun hipotesis dalam penelitian ini yaitu pelatihan pengendalian diri efektif untuk mengatasi perilaku bullying siswa. Adapun hipotesa statistik yaitu :

$\mathrm{H}_{0}$ : Pelatihan pengendalian diri tidakefektif untuk mengatasi perilaku bullying siswa. $\mathrm{H}_{1}$ : Pelatihan pengendalian diri efektif untuk mengatasi perilaku bullying siswa.

\section{METODE PENELITIAN}

Model yang digunakan dalam penelitian ini yaitu model eksperimen dengan menggunakan pelatihan pengendalian diri untuk mengatasi perilaku bullying siswa di sekolah. Sesuai dengan jenis penelitian dan masalah yang dikemukakan, maka rancangan penelitian ini adalah the One-Group Pre-Posttest Design. Sampel yang terlibat dalam penelitian ini sebanyak 24 siswa. Teknik pengambilan sampel yang digunakan yaitu purposive sampling.

Untuk mengumpulkan data yang diperlukan dalam penelitian ini, digunakan instrumen penelitian. Instrumen penelitian yang digunakan adalah angket yag berupa Pre Test dan Post Test. Pre Test dan Post Test yang disusun terdiri atas 3 aspek yaitu aspek bullying fisik, bullying verbal, dan bullying mental. Analisis Statistik Inferensial digunakan untuk menguji hipotesis penelitian dan mengambil kesimpulan keadaan populasi yang sedang diteliti, berdasarkan hasil penyelidikan sampel. Uji t atau t-test dalam penelitian ini dilakukan menggunakan software SPSS 16.0

\section{HASIL}

Berdasarkan hasil uji $\mathrm{t}$ pada tabel, didapat $\mathrm{t}$ hitung sebesar 7.232. $\mathrm{t}$ tabel dilihat pada tabel statistik, maka hasil yang diperoleh untuk $\mathrm{t}_{\text {tabel }}$ sebesar 1.714. Nilai $\mathrm{t}_{\text {hitung }}>$ $\mathrm{t}$ tabel $(7.232>1.714)$ maka $\mathrm{H}_{0}$ ditolak dan $\mathrm{H}_{1}$ diterima. Adapun hipotesa penelitian yaitu $\mathrm{H}_{1}$ yaitu efektif diterima. Hal ini berarti bahwa pelatihan pengendalian diri efektif untuk mengatasi perilaku bullying siswa. Disamping itu juga bahwa terdapat penurunan skor total aspek yang signifikan yaitu skor total pretest adalah 339 dan skor total posttest adalah 94 . Hal ini membuktikan bahwa adanya upaya perbaikan diri dari peserta pelatihan dalam aspek-aspek yang dipakai untuk mengukur perilaku bullying yang mereka miliki. Berdasarkan data yang diperoleh diatas maka 
disimpulkan bahwa terbukti pelatihan pengendalian diri efektif untuk mengatasi perilaku bullying siswa.

Berdasarkan hasil lembar kerja yang diberikan selama pelatihan, maka didapati bahwa subjek yang berperilaku bullying telah mengenal serta mengetahui kelebihan/potensi yang dimiliki oleh dirinya. Selain itu, mereka juga mampu untuk menggali kekurangan yang dimiliki mereka. Hal ini berarti bahwa subjek cukup mengenal diri sendiri serta menyadari perilaku-perilaku negative yang dimilikinya. Subjek mampu untuk mengungkapkan semua hal tentang kelebihan dan kekurangan diri mereka sendiri. Disamping itu, mereka juga tahu penilaian orang lain tentang diri subjek. Subjek sadar bahwa orang lain menilai mereka secara negative karena perilakunya.

Subjek juga diberikan kesempatan untuk mengungkapkan situasi-situasi yang disukai dan tidak disukainya. Hal ini bertujuan untuk mengetahui kemungkinan perilaku subjek yang akan muncul ketika berhadapan dengan situasi-situasi yang menyenangkan atau situasi-situasi yang tidak menyenangkan. Jika subjek sudah dapat memprediksikan kemungkinan perilaku yang akan muncul maka subjek dapat mengontrol perilaku yang akan muncul, terutama perilaku yang negative.

Setelah subjek mampu menilai dirinya sendiri, subjek diberikan pengetahuan tentang cara merubah perilaku-perilaku tersebut dan konsekuensinya. Sehingga subjek dapat menerapkannya dalam kehidupan sehari-hari baik di sekolah maupun di rumah. Keinginan subjek untuk merubah perilaku dapat dilihat dari komentar salah satu subjek, yaitu

"Ibu, saya tidak ingin berkelahi lagi. Saya berharap dengan langkah-langkah yang ibu berikan bisa membantu saya untuk tidak berkelahi dan dapat mengontrol emosi saya"

Berdasarkan komentar diatas, maka dapat dikatakan bahwa subjek berkeinginan untuk merubah perilaku yang negative, serta mengembangkan perilaku yang positif. Disamping itu, subjek juga mampu untuk mengambil tindakan yang tepat dalam menghadapi permasalahan yang dimilikinya. Subjek akan berpikir terlebih dahulu sebelum bertindak sehingga tidak mennimbulkan konsekuensi yang buruk dari perilakunya.

\section{PEMBAHASAN}

Dengan terujinya hipotesis maka sebenarnya membuktikan secara empiris bahwa pelatihan pengendalian diri efektif untuk mengatasi perilaku bullying siswa. Materi dalam pelatihan ini bertujuan untuk membantu subjek lebih mengenali diri sendiri, potensi-potensi yang dimiliki, serta sifat-sifat yang dimilikinya sehingga subjek menjadi semakin paham akan proses-proses psikologis yang terjadi pada dirinya. 
Melalui pelatihan ini juga merupakan media alternatif yang efektif dalam membantu subjek untuk lebih terbuka terhadap kelemahan-kelemahan serta kekurangan-kekurangan yang ada pada dirinya. Proses pengungkapan diri diciptakan dalam suasana yang tidak mengancam, menyenangkan, dan tidak menimbulkan rasa tertekan. Dengan demikian setahap demi setahap subjek akan mulai mengungkapkan kelemahan-kelemahan dirinya. Selain itu juga, subjek diberikan kesempatan untuk mengungkapkan sifat-sifat serta perilaku negative yang sering dilakukan. Pelatihan pengendalian diri ini memberikan kesempatan pada subjek untuk mengungkapkan diri berarti mendorong individu untuk mulai menyadari siapa saya dan seperti apa dirinya. Selain itu, pelatihan pengendalian diri juga membuat subjek mau mempertimbangkan berbagai konsekuensi untuk perilaku tertentu.

Sebagaimana diungkapkan oleh Higgins (Tangney, 2004) bahwa kesadaran diri merupakan langkah pertama untuk memahami diri dan menentukan pilihan apakah seseorang perlu mengubah pola perilaku yang sudah ada agar lebih efektif. Pengungkapan diri di samping membantu individu untuk mengenali dirinya sendiri juga sekaligus membimbing ke arah tujuan hidup yaitu saya ingin menjadi siapa. Artinya, setelah menyadari kelemahan dan kekuatan, maka seseorang dibimbing untuk menentukan tujuan-tujuan hidupnya.

Materi di dalam pelatihan pengendalian diri ini menggali tiga aspek dalam diri subjek, yang pada akhirnya subjek mampu mengenali diri sendiri, setelah itu subjek mampu mengendalikan keinginan di dalam dirinya serta mampu merubah stimulus yang tidak menyenangkan menjadi menyenangkan. Selain itu juga, subjek mampu memahami dan mengenali serta menilai suatu keadaan lingkungannya dengan baik sehingga bisa menunjukkan perilaku yang positif. Pada akhirnya subjek sudah mampu mengambil tindakan atas permasalahan yang dihadapi serta dapat mempertimbangkan konsekuensi sebelum mengambil suatu tindakan.

Hal ini menjawab pendapat dari Averil (Ghufron dan Risnawita, 2010) yang mengemukakan bahwa pengendalian diri terdiri dari 3 aspek yaitu pengendalian perilaku, pengendalian kognisi, dan pengendalian keputusan. Dalam pelatihan pengendalian diri, subjek diberikan kesempatan untuk mengembangkan ketiga aspek pengendalian diri tersebut. Sehingga pada akhirnya subjek mampu untuk melakukan pengendalian diri untuk mengatasi perilaku bullyingnya.

\section{KESIMPULAN}

Berdasarkan hasil penelitian yang telah dilakukan, maka dapat diambil kesimpulan sebagai berikut :

1. Pelatihan pengendalian diri efektif untuk mengatasi perilaku bullying siswa. Hal ini terbukti dengan nilai $t_{\text {hitung }}>t_{\text {tabel }}(7.232>1.714)$. 
2. Terdapat penurunan skor total aspek yang signifikan yaitu skor total pretest adalah 339 dan skor total posttest adalah 94. Hal ini membuktikan bahwa adanya upaya perbaikan diri dari siswa untuk mengurangu perilaku bullying yang mereka miliki.

3. Subjek mampu untuk melakukakn pengendalian perilaku, pengendalian kognisi, dan pengendalian keputusan sehingga perilaku bullying subjek dapat dihilangkan.

\section{DAFTAR PUSTAKA}

Astuti, D. R. 2008. Meredam Bullying: 3 cara efektif menanggulangi kekerasan pada anak. Jakarta: PT.Grasindo

Chapple. L. C., (2005). Self-control, Peer Relations, and Delinquency. Justice Quarterly. 22 (1), 89-96

Denson, T. F., Dewall, C. T., Finkel. E. J. (2012). Self-control and aggression. Current directions in psychological science, 21(1), $20-25$

Ghufron, M. N., \& Risnawita, S. 2009. Teori-Teori Psikologi. Jakarta: Gramedia

Mudjijanti, Fransisca. 2011. School Bullying dan Peran Guru Dalam Mengatasinya. Naskah Krida Rakyat. Tidak Diterbitkan

Santrock, J. W. 2002. Life Span Development (Perkembangan Masa Hidup). Jilid 1. Jakarta: Erlangga

Sejiwa. 2007. Bullying: Panduan bagi Orangtua dan Guru. Mengatasi Kekerasan di Sekolah dan Lingkungan. Jakarta:Grasindo

Soendjojo, D. 2009. Mengajarkan Asertifitas Pada Remaja. Jurnal Psikologi. 4, (3), 5-7

Sumiarni, Endang 2009. Kekerasan di Sekolah dan Hak Anak dalam Perspektif Hukum. Makalah Seminar "Fenomena Kekerasan di Sekolah dan strategi Pencegahannya", 2 Agustus 2009, FIP UNY

Tangney, J. P., Baumiester, R.F., \& Boone, A.L.(2004). High Self Control Predicts Good Adjusment, Less Pathology, Better Grades, and Interpersonal Succes. Journal of Personality.72 (2). 271-322

Wicaksono. 200. Pentingnya Sebuah Keyakinan Diri. (online). http://aryowicaksonobp.blogspot.com/2007/12. diunduh tanggal 15 Februari 2015. 